\title{
THE FOURTH DEVELOPMENT CABINET ANNOUNCED MARCH 17, 1983
}

\author{
Prepared by the Editors
}

For the benefit of our readers we thought it was useful to provide a list of the new cabinet, supplemented by biographical data we have been able to gather from a variety of published and unpublished sources.

Key to Signs, Symbols, and Abbreviations

Names underlined $=$ New members of the cabinet (i.e., not in it in February 1983)

Ir

(R)

SE

$\mathrm{SH}$
$=$ Insinyur (holder of engineering degree)

$=$ Retired

= Sarjana Ekonomi (Master of Economics)

= Sarjana Hukum (Master of Law)

The Fourth Development Cabinet

State Secretariat

1) Minister of State/State Secretary

Lt. Gen. Sudharmono, SH

b. March 12, 1927 in Gresik, East Java

In the colonial period had a HIS education. After the war, finished high school and graduated from the Military Law Academy, the Military Law College (Perguruan Tinggi Hukum Militer), the Reserve Officers' School, and Seskoad (Staff and Command School, Bandung). During the Revolution was an obscure second lieutenant in Djatikusumo's Ronggolawe Division (North Central/East Java). Between 1950 and 1952 was attached to the Army Officers' Education Center in Bandung, and spent the following four years at the Military Law Academy. From 1957, now a qualified Military Prosecutor, worked on the staff of Nasution's Peperpu (Central Martial Law Administration) until 1961. By 1962 was a Substitute High Military Prosecutor (Jaksa Tentara Tinggi Pengganti), and head of the secretariat of Peperti (Peperpu's successor). In the last two years of the Old Order, was on the secretariat of the MPPR (Peperti's successor), assistant for special (i.e., intelligence) affairs of KOTI's Gabungan V under Achmadi, and Second Deputy Head of the Central Team for Disciplining State Personnel. In 1966, became Cabinet Secretary, and in 1967 member for "general affairs" on Suharto's SPRI (Personal Staff). Also served as Chairman of the Coordinating Committee for Foreign Technical Cooperation ; Secretary of the Economic Stabilization Board; and Secretary of the Team for Inspection of State Finances. In the Second Development Cabinet was Minister of State for the Administration and Finance of Non-Departmental State Agencies, as well as replacing Alamsjah as State Secretary. Is brother-in-law of former Governor of Central Java, Maj. Gen. Munadi. 
2) Junior Minister/Cabinet Secretary

Brig. Gen. Drs. Moerdiono

b. August 19, 1934 in Banyuwangi, East Java

Enrolled at the Ministry of the Interior's Public Administration Academy in Malang in 1957. At the start of the New Order was an aide to General Sudharmono and has been attached to him ever since. Was Cabinet Secretary under previous cabinet, but without ministerial rank.

\title{
Coordinating Ministers
}

3) Coordinating Minister for Politics and Security

\author{
Gen. (R) Surono Reksodimedjo \\ b. September 6, 1923, in Banyumas, \\ Central Java \\ (son of Tjokrosiswojo, bupati of Cilacap)
}

Graduated from MULO in the colonial period; later military education included training in the wartime Peta (1943-45), Seskoad (Class IV), the War College (HKS) in West Germany, the American General Staff and Command School at Fort Leavenworth (1958) and the Kodokan Judo Institute in Japan. During the Revolution, fought for the Republic in the Banyumas area under Gatot Subroto. After 1950 served successively as: commander of Battalion 402/Diponegoro (1951); aide to Army Chief of Staff Col. Nasution (1951); Chief of Staff, Regiment 14 (Semarang-Salatiga) under Maj. Pranoto Reksosamudro (1953-55); Chief of Staff, Regiment 15 (Solo) under Lt. Col. Pranoto Reksosamudro (1955-57); commander of the Diponegoro Division's anti-Darul Islam Banteng Raiders (1957) under Col. Soeharto. In 1958, taught at the Army Staff and Command School, and in 1960 became Deputy Governor of the Military Academy in Magelang. From 1961 to 1966 was the Academy's Governor. In the early part of 1966 served concurrently as Deputy for Operations to Army Commander Soeharto and as acting commander of Kodam VII, replacing Brig. Gen. Surjosumpeno ad interim. Was full-time Diponegoro commander from September 1966 to December 1969, when rose to commander of the newly established Kowilhan II (JavaMadura). In April 1973, became Army Chief of Staff; and in May 1974 Deputy Commander of the Armed Forces. In April 1978, left military service to become Coordinating Minister for Social Affairs.

4) Coordinating Minister for Economics, Finance, Industry, and Development Control
Prof. Dr. Ali Wardhana

b. May 6, 1928 in Solo, Central Java

After graduating from the Faculty of Economics, University of Indonesia, in 1958, continued studies in economics at the University of California at Berkeley where achieved doctorate in 1962. On his return, rejoined the University of Indonesia Economics Faculty, rising eventually to the rank of Professor. From 1962 to 1967 directed the Faculty's Economic and Social Research Institute. From 1965 lectured regularly at the Seskoad and the National Defense Institute. In 1966 became a member of the President's Economic Advisory Team, and the following year Dean of the University of Indonesia's Economics Faculty, holding this job until 1978. From 1968 to 1983 has been Minister of Finance. 
5) Coordinating Minister for Public Welfare

\author{
Lt. Gen. (R) Alamsjah Ratu \\ Prawiranegara \\ b. December 25, 1925 in Kotabumi, \\ Lampung, South Sumatra \\ (son of a local marga chieftain)
}

In the colonial period attended a private HIS in his home district. At some later point evidently completed high school. Entered the Japanese-sponsored Giyugun auxiliary military force in 1943, and achieved the rank of second lieutenant. During the Revolution, was active in the army on the Palembang and Lahat fronts, at one point in 1947 serving as Acting Chief of Staff of Division II (Garuda). By the Revolution's end was Assistant-2 to the South Sumatra Brigade commander, and when TT/II (S. Sumatra) was established under Bambang Utojo in 1950 , held the same position in it. In 1953-54 held the Palembang Municipality Command. When Ibnu Sutowo took over as commander of TT/II in 1954, became his intelligence chief (Assistant-1). By 1958, at the height of the regional crisis, had become divisional chief of staff. Then sent off to study in India by an Army High Command that suspected him of rebel sympathies. On return, assigned to staff duties in Bandung (1959) and at Army HQ under First Deputy Maj. Gen. Soeharto (1960). In 1961-62 was sent to Fort Leavenworth for further training, and on return was assigned to reorganize the army's internal financial system. In 1963, as colonel, became Deputy Assistant-7 (finance) to Army Commander Yani, and a year later Assistant-7, with the rank of Brig. Gen. In the early New Order period was made Coordinator of the President's SPRI (Personal Staff), and the following year was promoted and took on the additional job of Third Deputy (special affairs) to Soeharto in his capacity as Army Commander. From 1969-72 was State Secretary and from 1972-74 Ambassador to The Hague. In 1975 was appointed to the Supreme Advisory Council, becoming its Deputy Chairman in 1977. In the Third Development Cabinet (1978-83) served as Minister of Religion.

Ministers of State

6) Minister of State for National Department Planning/Chairman of Bappenas
Prof. Dr. Johannes B. Sumarlin

b. December 7, 1931, in Blitar, East Java

Was a member of the Indonesian Red Cross in the final stages of the Revolution, and in the 1950s worked for Sar's Industry, a manufacturing concern in Jakarta, while studying economics at the University of Indonesia. In 1960, obtained an MA from the University of California at Berkeley, and then returned to teach at his alma mater. Sometime after 1964 went back to the US and got his doctorate from the University of Pittsburgh. At the end of the 1960s became Deputy Chairman of Bappenas, and was made Minister of State for Reform of the State Apparatus in the Third Development Cabinet (1978-83). Is a Catholic .

7) Minister of State for Research and Technology /Chairman of the Board of Research and Application of Technology
Prof. Dr. Ir. Bacharudin Jusuf ("Rudy") Habibie

b. June 25, 1936, in Pare-Pare, South Sulawesi

Was educated at the Bandung Institute of Technology (1954-55) and the University of Aachen in West Germany (1955-60). Then worked as Research Assistant at 
Aachen's Technical High School, and from 1966-69 as head of the research division of the Messerschmitt-Bolkow-Blohm Corporation. After that he was its Vice President in charge of the application of technology; adviser to the director-in-chief of Pertamina (Ibnu Sutowo) as well as head of Pertamina's Division of Advanced Technology/Aeronautical Technology, both in 1974. Since 1976 has been Director-inChief of PT Nurtanio (aeronautical assembly and manufacture), and since 1978 Minister of State in charge of Research and Technology.

\section{8) Minister of State for Demography and the Environment}

Prof. Dr. Emil Salim

b. June 8, 1930, in Lahat, South Sumatra

During the Revolution, was active in South Sumatra, especially as chairman of the Student Army in Palembang, from 1946 on. At the Revolution's end was in West Java, working as chairman of the Bogor branch of IPPI (Ikatan Pemuda Pelajar Indonesia), and member of the Siliwangi Student Mobilization Corps. During the 1950 s studied economics at the University of Indonesia and went on to get a PhD from the University of California at Berkeley. On his return taught regularly at his alma mater, as well as at Seskoad, Seskoal (Seskoad's Navy equivalent), the Police College, and elsewhere. A member of the Economic Advisory Team for Soeharto in 1966, became Deputy Chairman of Bappenas (National Development Planning Agency) in charge of Material and Infrastructural Planning in 1967, as well as sitting as a member of Parliament and the MPRS. Was an active member of many delegations to meetings of the IGGI, IMF, IBRD, etc., in 1967-70. In 1971-73 was Minister of State in charge of Perfecting and Purifying the State Apparatus, as well as being a Deputy Chairman of Bappenas under Prof. Dr. Widjojo Nitisastro. In the Second Development Cabinet (1973-78) served as Minister of Communications, and in the Third (1978-83) as Minister of State for Supervision of Development and the Environment. Remains a Professor of Economics at the University of Indonesia.

9) Minister of State for Public Housing

Drs. Cosmas Batubara

b. September 19, 1938, in Purbasaribu, Simalungun, North Sumatra

A sometime student of journalism, achieved initial prominence as General Chairman of the Catholic student organization PMKRI in the last years of Guided Democracy. Working closely with Kostrad and the Opsus apparatus, was active in organizing the student demonstrations that helped to overthrow Sukarno in 1966. In that year headed the Presidium of KAMI, the Student Action Front. Became a member of Parliament in 1967 and served till 1978 when became Junior Minister for Public Housing. Is General Chairman of the state-controlled youth organization KNPI and a member of Golkar's Central Leadership Council.

10) Minister of State for Youth and Sport
Air Major Dr. Abdul Gafur Tengku Idrus

b. June 20, 1938, in Halmahera, North Moluccas

Graduated from the University of Indonesia's Medical Faculty in 1966, but had become a junior Air Force officer already in 1964. In 1967-68 headed the General Health Division of the Air Force Hospital at the Abdurachman Saleh airbase in Malang. From 1968-70 headed the Hygiene and Polyclinic Section of the Surabaya airbase's hospital. Was a member of Parliament (Armed Forces' Fraction) from 1972 to 1978, when rose to become Junior Minister in charge of Youth Affairs. Associated with the Center for Strategic and International Studies/Opsus group. 
11) Minister of State for Reform of State Apparatus/Deputy Chairman of Bappenas
Mr. Saleh Afiff

b. October 31,1930 , in Cirebon, West Java

After initial study at the University of Indonesia's Economics Faculty, went on to acquire an MBA in California in 1961, and a doctorate in Agricultural Economics from the University of Oregon in 1967. Served as Deputy for Economic Affairs to the Chairman of Bappenas (Widjojo Nitisastro) from 1973-83; and Assistant to Coordinating Minister for Economics, Finance, Industry, and Development Control (Widjojo again) from 1978-83. Has been a member of, and chairman of, various Indonesian delegations in bilateral and multilateral aid negotiations (1967-1980).

12) Minister of State for Women's Affairs
Mrs. Lasiyah Sutanto

b. August 13, 1924, in Bantul, Yogyakarta (Central Java)

A graduate of Gadjah Mada University, and with a diploma from the Sorbonne, has been a Professor of Law at Gadjah Mada and Atmajaya Universities. Was Minister for Women's Affairs in the previous cabinet.

Departmental Ministers

13) Minister of the Interior

Lt. Gen. (R) Supardjo Rustam

b. August 12, 1926, in Sokaraja, Banyumas, Central Java

Received his first military training as member of the Peta in Banyumas during the later Japanese Occupation period (1944-45). During the Revolution served mainly as personal ADC to the commander of Division V (Kedu and Banyumas) from March 1946 to March 1948, when rose to become Commander-in-Chief Sudirman's personal ADC until the latter's death in January 1950. After almost a year in East Kalimantan as a battalion commander, returned to become Armed Forces' Chief of Staff Col. T. B. Simatupang's ADC (November 1950-June 1951). There followed two months taking the Infantry Officer's Basic Training Course at Fort Benning (June to September 1951). Seems then to have served as Military Attache in the Netherlands for an unspecified period. In November 1959 became Military Attache in Kuala Lumpur, probably till 1962. In 1964 was general secretary of the powerful superagency Kotrar (Command for Retooling the State Apparatus) and stayed in this post till it was abolished in the early New Order period. Played an important role in the diplomacy ending Confrontation. In 1967 headed the Foreign Ministry's Directorate for Southeast Asia. In 1969 that for East Asia and the Pacific. Went to serve for two years as Ambassador to Belgrade (1971-72), and three years as Ambassador to Kuala Lumpur (1972-74). Became Governor of Central Java in 1974.

14) Minister of Foreign Affairs

Prof. Dr. Mochtar Kusumaatmadja

b. February 17, 1929.

Got his legal training at the Law Faculty of the University of Indonesia, Yale Law School, Harvard Law School, and the University of Chicago Law School, before gaining a doctorate from Pajajaran University in 1963. Taught international law at Pajajaran University and the University of Indonesia, specializing in the law of the 
sea. Became Foreign Minister in the Third Development Cabinet, succeeding Adam Malik.

15) Minister of Defense and Security

General (R) S. Poniman

b. July 18, 1926, in Solo, Central Java

In late colonial period, had a HIS and MULO education, and during the Japanese Occupation was recruited into the Peta. During the Revolution, started as a company commander and worked his way up within the ranks of the Siliwangi Division to the position of Military Resort Commander in 1959. In 1965, became Chief of Staff of Kodam III in West Sumatra, and in the spring of 1966 commander. After two years in West Sumatra, was transferred to Ambon to serve as commander of Kodam XV between August 1968 and March 1970; as commander of Kodam V in Jakarta (March 1970 to April 1973) ; commander of Kostrad (April 1973 to May 1974); commander of Kowilhan I-Sumatra (May 1974 to October 1977); Deputy Army Chief of Staff (October 1977 to April 1980); and Army Chief of Staff (April 1980 to March 1983).

16) Minister of Justice

\author{
Lt. Gen. Ali Said SH \\ b. June 12 , 1927, in Magelang, Central \\ Java
}

In the colonial period graduated from a HIS (1942). Claims oddly to have completed MULO in 1945. Took part in the Revolution in the Pekalongan-Wonosobo area, and passed a Reserve Officers' Training Course in 1946. In 1950 was sent to Balikpapan and served as adjutant to the commander of Military Subterritorium IV (Balikpapan); the next year became adjutant to the commander of $T \& T$ VI Kalimantan (possibly Col. Sadikin). After four years of minor staff jobs in Jakarta and Bandung, was sent to the Military Law Academy in 1956, where he studied on and off for next 4 years. Concurrently served as military prosecutor in Denpasar, and later for the whole military region of East Indonesia. Headed Kodam 16's Courts Martial in 1960-62; the Organization Section of the Army's Legal Directorate in Jakarta in 1962-63; and the Jakarta Courts Martial in 1962-66. Became a well-known public figure as Presiding Judge of the Extraordinary Military Tribunals trying leading figures of the September 30th Movement and the Indonesian Communist Party in 1965-66 (Nyono and Subandrio in particular). After brief stints as Assistant-3 (Personnel) at the Army's Legal Directorate and Assistant-5 in Kodam8/Brawijaya (1966-69); became in May 1969 Deputy [Junior] Attorney-General. In 1972, rose to become AttorneyGeneral. In mid-February 1981 replaced Maj. Gen. Moedjono SH as Minister of Justice.

17) Minister of Information

\author{
$\underline{\text { Harmoko }}$ \\ b. February 7, 1939, in Kertosono, \\ East Java
}

Has a high school education, but considerable journalistic experience, and has been at tached to the National Defense Institute. Started working as a reporter in 1960, and after 1965 headed the editorial office of Pos Kota, the lurid newspaper originally sponsored by the Greater Jakarta Municipality regime of Ali Sadikin. After 1970, became a leading figure in the Indonesian Journalists' Association, first at the Jakarta branch level, later at the national level. Is a member of the Press Council, and of Parliament and the MPR. 
18) Minister of Finance
Drs. Radius Prawiro

b. June 29,1928 , in Yogyakarta, Central Java

Has MA degrees from the School of Economics in Rotterdam, and the Faculty of Economics, University of Indonesia (in Accountancy). During the Revolution, was successively secretary of the Yogyakarta BKR (Badan Keamanan Rakyat) and TKR (Tentera Keselamatan Rakyat) in 1945-46; member of the Ikatan Pelajar Indonesia's Defense Service (1946); officer in the Code Department of the Army Communications HQ (1947-48); and head of the welfare section of Section II, Company II, Detachment III, of the Student Army-based Brigade 17 (1949-51). After completing his economic studies, became a technical assistant at the State Audit Directorate (19601964), and Deputy Minister for State Audits/member of the Supreme Auditing Council in 1965. Under the New Order has been Deputy Minister for Central Bank Affairs/Governor of the State Bank (1966-73); Minister of Trade (1973-78); and Minister of Trade and Cooperatives (1978-83). Is a Protestant.

19) Minister of Trade

Rachmat Saleh SE

b. May 1, 1930, in Surabaya, East Java

After graduating from the University of Indonesia's Economics Faculty in 1955, was hired as a clerk on the General Staff for Economic Statistics (1956), then at tached to the Reserve Bank of India in Bombay (1957). In 1958 acted as temporary representative of the Bank of Indonesia in America and as secretary to the Bank's mission in the Netherlands. In 1960 was Acting Head of the Bank's Economic Statistics Division, and the following year Acting Deputy Director for both Economic and Development Affairs and Economic and Statistical Affairs at the Bank. In the late Old Order, continued to rise at the Bank, becoming Deputy Director for Foreign Affairs in 1962 and Head of Research in 1964. In 1966 became a Director, and subsequently Governor of the Bank.

20) Minister for Cooperatives

\author{
Lt. Gen. (R) Bustanil Arifin SH \\ b. October 10, 1925, in Padang Panjang, \\ West Sumatra
}

In the late colonial period (1940-42), worked as a clerk in a legal firm, and under the Japanese carried on this line of activity in the Japanese military administration in Aceh. During the Revolution, rose to be a company commander in the same region. After 1950, seems to have spent time as an instructor at Army's Logistics Training Center at Cimahi. Under Guided Democracy was a member of the DPRGR and MPRS and head of the Department of Education and Administration in the Armed Forces' Logistics Directorate (in Jakarta). Became nationally famous as Deputy for Supply and Distribution of Rice in Bulog, the state "logistics" agency dealing with foodstuffs (1969-71). Later served as secretary of the PL 480 Team, the Food Aid Team, and Sector $H$ of the Five Year Development Plan. Has been Consul-General in New York; and most recently Junior Minister for Cooperatives, doubling as Head of Bulog. Holds a law degree from Pajajaran University.

\section{1) Minister of Agriculture}

\author{
Ir. Achmad Affandi \\ b. October 27, 1927, in Kuningan, \\ West Java
}

Graduated from the Agricultural Faculty at Bogor in 1958, and later studied at the University of Kentucky. During the Revolution served in the Tentera Pelajar 
(Student Army of Central Java), and worked for a time as a teacher in high schools and teacher training colleges. Between 1962 and 1964 was head of the Bureau of Supplies in the Ministry of Higher Education as well as Lecturer at the Bogor Agricultural Faculty. In 1965-67 was a senior official seconded to the Department of Defense and Security. From 1968-69, served as Director-General for Animal Husbandry;as Agricultural Attache for Western Europe in The Hague; as secretary of the Control Board for BIMAS (1971-73); Director-General for Foodstuffs, and lastly Junior Minister for Foodstuff Production.

22) Minister of Forestry

\author{
Sudjarwo \\ b. April 15, 1922, in Wonogiri, Central \\ Java \\ (son of Raden Ngabehi Reksosaroyo, \\ middle-level forestry official of the \\ Mangkunegaran)
}

In colonial period attended MULO in Jakarta and Intermediate Forestry School (Middelbare Bosbouwschool) in Madiun. Under the Japanese, worked from August 1942 on as head of the Forestry Service in Jombang. In 1948-49, was commander of Battalion VII Pasukan Gerilya "Wanara" attached to command of (then) Lt. Col. Sudirman in the Surabaya area; later member of the Operations Staff of Division I under Col. Sungkono. From 1951-53 attended the Forestry Academy in Bogor, and on graduating became head of the Forestry Service in West Banyumas. From 1958 headed Forestry Service of Yogyakarta and was technical advisor on forestry matters to the Yogyakarta legislature. Between 1964 and 1966, served under Sukarno as Minister of Forestry. Under the New Order, has served as Director-General for Forestry ; also Chairman of the Sarana Wana Jaya Foundation (1973) ; First Treasurer of the Supersemar Foundation (1974) ; Second Treasurer of the Mangadeg Foundation (1969); Secretary-General of the Dana Margasatwa (Wild Life) Foundation; and head of the Silk Consultation Board. Only current minister to have served in same capacity under the Old Order.

23) Minister for Industry

Ir. Hartarto Sastrosoenarto

b. May 30,1932 , in Delanggu, Central Java

Was sent under the Colombo Plan to study chemical technology at the University of New South Wales, and graduated cum laude in 1958. Has been Director-General for Basic Chemical Industry in the Department of Industry.

24) Minister for Mining and Energy

Prof. Dr. Subroto

b. September 19,1928 , in Solo, Central Java

After obtaining an MA at the Economic Faculty of the University of Indonesia in 1952, studied for a time at McGill University in Montreal, before getting his $\mathrm{PhD}$ back at his alma mater in 1958. Professional career began with teaching at the University of Indonesia. Under the New Order became successively DirectorGeneral for Research and Development in the Ministry of Trade; Minister for Transmigration and Cooperatives (1971-73); Minister for Manpower, Transmigration, and Cooperatives (1973-78); and Minister for Mining and Energy (1978-83). 
25) Minister of Public Works
Ir. Suyono Sosrodarsono

b. March 3, 1926, in Madiun, East Java

In the colonial period was educated in the European Primary School (ELS) and the HBS up to Grade III; later in Indonesian high schools and finally at the Institute of Technology in Bandung. Was an official in the Bureau for Public Housing from 1955 to 1958, and rose to be the Bureau's head from 1958-60; headed the South Sumatra Public Works Office from 1960-63; and ran the Directorate for Construction and Disaster Prevention Project from 1963-66. In 1965-66 was Chief Assistant to the Minister of Irrigation before serving as Director-General of Irrigation from 1966-82. Since 1982 has been Secretary-General of the Department of Public Works.

26) Minister of Communications

Air Marshal Rusmin Nurjadin

b. May 31, 1930, in Malang, East Java

During the Revolution was attached to Detachment III of the Student Army-based Brigade 17. In 1951-52 attended Flight School at Kalijati, near Bandung. By 1954 had risen to become acting commander of Squadron III (P-51 fighters), then left for England to learn to fly jet planes at the RAF's Flight Instructor School (1955). On his return, became full commander of Squadron III at Halim airbase. In 1958 was made acting commander of Squadron XI (Vampire jet fighters) at Halim, and the following year spent three months in Poland studying tactical and operational aspects of fighterplane warfare. In 1960 returned to Squadron III briefly before being sent for further study at the Defense Service Staff College in India. On his return a year later, rose by 1962 to become deputy head of the Air Force's Operations Command at Halim airbase, and by 1963 commander of the Air Defense Command (Kohanud)/Chief of Staff of the National Air Defense Command (Kohanudnas). Was then sent to serve as Air Attache in Bangkok (1963-64) and Moscow (1964-65). Late in 1965 was recalled to become Deputy for Operations to the Air Force commander, succeeding his superior during the crisis of March 1966. In the 1970s resumed a diplomatic career as Ambassador in London (1970-74) and Washington, DC (1974-77). In 1978 was appointed Minister of Communications in the Third Development Cabinet. Is also Chairman of the Telecommunications Council and a member of the Council on Free Trade Zones and Ports.

27) Minister of Tourism, Posts, and Telecommunications

\author{
Lt. Gen. (R) Ahmad Tahir \\ b. June 27, 1924, in Kisaran, North \\ Sumatra \\ (father, Haji Achmad, was originally \\ from Salatiga, Central Java)
}

Received early military training in the Giyugun, established by the Japanese 25th Army in 1943. After the outbreak of the Revolution, became a prominent Republican military commander in the Medan area and played a key role in suppressing the so-called "Social Revolution" there in April-May 1946. In 1948-49 was Chief of Staff to the Sumatra commander. During the $1950 \mathrm{~s}$, attended the Candradimuka Military School near Bandung (1952); an Officers' Advanced Course in America (1953); a Military Attaches' Course in Jakarta (1956); and the General Officers' Course (C) at the Bandung Seskoad in 1960 (Class II). In 1953, was deputy head of Section III of Army Headquarters, and became head a little later. In 1956, was sent as Military Attache to Rome; serving until at least 1958. After a brief stint as teacher at Seskoad, became in 1962 Chief of Staff to Soeharto in the Mandala Command, which was responsible for operations to liberate West Irian. In 1966, replaced Surono as Governor of the Military Academy, which in 1967 became the Army and 
General Division of the Armed Forces' Military Academy. In 1968, moved to Jakarta to become Third Deputy (Special Affairs) to the Minister for Defense and Security (Soeharto); in November 1969, appointed to command the newly established Kowilhan I (Sumatra). In 1973, transferred to become Ambassador to France (1973-76) and Spain (1973-75). In 1976, became Secretary-General of the Department of Communications.

28) Minister of Manpower

\author{
Admiral (R) Sudomo \\ b. September 20, 1926, in Malang, East \\ Java
}

In the colonial period was educated in HIS and MULO, and during the war at the Sekolah Pelayaran Tinggi. In 1948, attended Basic Naval Officers' Training at Sarangan, near Madiun, and from 1951-53 had further instruction from the Dutch Navy at Den Helder, the Netherlands. During the 1950s, held a series of ship commands, as well as receiving Destroyer Commander training in Poland in 1958. In 1959 , became Chief of Staff of the Fleet (Armada), and in 1961 Director of Operations at Naval Headquarters, helping plan anti-Dutch operations in the environs of West Irian. In 1962, was made Soeharto's Deputy in the Mandala Command for the Liberation of West Irian, and commander of its naval component. In 1964, moved into the field of communications and transportation as Chief of Staff of Operations Unit III of the KOTOE (Supreme Economic Operations Command), and in 1965 became aide to the Minister of Sea Communications, in charge of operations. From 1966-68 was Inspector-General of the Navy, before being inaugurated in September 1968 as the first commander of the Central Naval Area Theater Command, based in Makasar. In December 1969, succeeded Muljadi as Navy Chief of Staff, a position he held until June 1973. In July, succeeded General Sumitro when the latter moved up from deputy commander to commander of Kopkamtib. The Malari riots of mid-January 1974 brought about Sumitro's disgrace and abolition of the post of deputy commander of Kopkamtib. In its place came a Chief of Staffship which Sudomo took over on January 18, 1974. In April 1978, in the wake of the student protests of January and February, became the head of Kopkamtib and also deputy commander of the Armed Forces. Became a Protestant after marrying a Menadonese woman.

29) Minister for Transmigration

Martono

b. May 17, 1925, in Karanganyar, Solo, Central Java

Was educated in colonial times in a HIS and a HIK (Teachers' Training School) in Yogyakarta. After independence, studied psychology at Leiden University. Between 1960 and 1964 was Cultural Attache in Tokyo. It is likely was involved in Isman's TRIP (Student Army) during the Revolution, since from 1964 to 1971 headed the central executive of TRIP's later avatar, KOSGORO. Has been (dates uncertain) a member of Parliament and the MPR, Chairman of the Film Censors' Board, and (in 1973) Chairman of Golkar's Central Leadership Council. Was Junior Minister for Transmigration Affairs prior to formation of the new cabinet.

30) Minister of Education and Culture

Prof. Dr. \& Titúlar Maj. Gen. Nugroho Notosusanto

b. June 15, 1931, in Rembang, Central Java

(son of the well-known legal scholar Prof. Notosusanto) 
At the beginning of the Revolution, was attached to the BKR in Jakarta, but later fought mainly in the Student Army-based Brigade 17 in the Kulon Progo area of Yogyakarta. On demobilization, attended the Faculty of Arts at the University of Indonesia, achieving a certain reputation as a student leader and writer of fiction. In 1960 joined the Arts Faculty of his alma mater. During Guided Democracy period, also taught regularly at Seskoad (then headed by a close relative, General Suwarto), and Seskoal. After a brief, unsuccessful period of study in England (1961-62), returned to become Assistant for Student Affairs to the University Rector in the critical 1964-67 period; also headed the Armed Forces' Staff Historical Center. In 1966 was made head of the Defense Ministry's Historical Institute, which in 1977 was renamed the Historical Center of the Indonesian Armed Forces. In 1977 gained his doctorate from the University of Indonesia, and in 1982 was appointed Rector of that university, a function he will retain in addition to his new ministerial position.

31) Minister of Health

$$
\begin{aligned}
& \text { Maj. Gen. (R) Dr. Soewardjono } \\
& \text { Soerjaningrat } \\
& \text { b. May 3, 1923, in Purwodadi, Central } \\
& \text { Java }
\end{aligned}
$$

In the colonial period spent five years in the elite HBS school system. During the Japanese Occupation received some military training. Between 1945 and 1950 served as head of the Planning and Organizational Staff of Regiment 6 of the Siliwangi Division's Brigade III (Cikampek area). In 1950 had a medical job with the Siliwangi Division while working for a medical degree from the University of Indonesia (achieved in 1954). After specialized studies in gynecology in 1957, became head of the Gynecological Department of the Army's Central Hospital, and held this job until 1970. In 1963, worked in America in hospitals run by Columbia, the State University of New York, Harvard, and Johns Hopkins. From 1968 an active figure in the Family Planning Institute. In January 1978 became secretary-general of the Department of Health, and, two months later, Minister.

32) Minister of Religion

Munawir Sjadzali MA

b. November 7,1925 , in Klaten, Central Java

(son of Kyai Mughafir, a Muhammadiyah notable in Karanganom, Klaten)

Educated at Jamsaren pesantren and the madrasah Mambaul Ulum in Solo, from which was graduated in 1942. During the Revolution active in Hizbullah and the GPII Muslim youth organization. In 1950, joined the Foreign Ministry. Later did further study at Exeter University and Georgetown University, Washington, DC (graduated 1958). Served in turn as Third Secretary, Embassy in Washington, DC; First Secretary, Embassy in Colombo; Minister Counselor, Embassy in London; Ambassador to Kuwait, Bahrain, Qatar, and the United Arab Emirates; head of the Directorate for Political Affairs, Department of Foreign Affairs. Associate member of the Institute for Strategic Studies in London.

33) Minister for Social Affairs

Mrs. Nani Sudarsono SH

b. March 28, 1928, in Purwodadi, Central Java

A law graduate of Gadjah Mada University, became in 1977 secretary-general of Kowani (Kongres Wanita Indonesia--Indonesian Women's Congress), and in 1980 General Chairman of the Himpunan Warita Karya (Women Functionaries' Association) 
and Chairman of Kerajinan Nasional (National Handicrafts). Is Deputy Chairman of Golkar's Central Leadership Council.

\section{Junior Ministers}

34) Junior Minister in Charge of Promoting the Utilization of Domestically Manufactured Products
Ir. Drs. Ginanjar Kartasasmita

b. April 9, 1941, in Bandung, West Java

Was educated at the elite Catholic Canisius High School of Jakarta (1953-59), the Bandung Institute of Technology (1959-60), and the Agriculture and Technology Faculty of Tokyo University (1960-65), from which he got his degree. Between 1970 and 1980 attended also the School of Public Administration and received an MA. Has also had considerable military education, including Basic Officer Training (1966-67), the Air Force's Sekolah Siasat in 1968, and its Commando School in 1974. On return from Tokyo in 1965, worked for KOTI's Gabungan V under Achmadi, and then in the Air Force's Directorate for Research and Development. Between 1968 and 1971 was head of the Research Section of the State Secretariat's Bureau for Development Analysis. After that became head of the Evaluation Section of the Cabinet Secretariat's Bureau for Foreign Technical Cooperation, and assistant to the Cabinet Secretary for State Administration Affairs (1976-78). Since 1977 has also been a member of the board of commissioners of PT Nurtanio; a member of the MPR ; and a participant in a number of task forces for tightening up the state apparatus. Before being assigned his current function, he served as assistant to the Minister/State Secretary in charge of state administrative affairs and administrative matters relating to nondepartmental state agencies.

35) Junior Minister in Charge of Increasing Food Production
Ir. Wardoyo

b. August 24, 1933, in Klaten, Central Java

Graduated from the Agricultural Faculty of Gadjah Mada University in 1962. In 1978 was appointed Director-General for Food Crops in the Department of Agriculture, and secretary of the Bimas Supervision Unit.

36) Junior Minister in Charge of Increasing Cash Crop Production
Ir. Hasrul Harahap

b. November 18, 1931, in Pematang: Siantar, North Sumatra

Graduated from the Bogor Agricultural Faculty in 1961, and did further work in economics at the University of North Sumatra in 1965. His early career was as Director of Production of PTP (Perusahaan Tanaman Perkebunan--Plantation Agriculture Enterprises) V in Sungei Karang, North Sumatra, and Chief Director of PTP XXIII in Surabaya. Before assuming his present ministerial post, he was head of the Staff for Upgrading State Enterprises (Staf Bina Perusahaan Negara).

37) Junior Minister in Charge of Increasing Production in Animal Husbandry and Fisheries
Prof. Dr. Johannes Humantal Hutasoit

b. September 16, 1925, in Siborongborong, North Sumatra

Studied animal husbandry at Bogor's Agricultural Institute and the University of Florida in Gainesville. Received his doctorate from Bogor in veterinary medicine. Served as Dean of the Faculty of Veterinary Medicine (1963-70), Chairman of the 
University Presidium and Acting Rector (1966-71), and Chairman of the Indonesian Agricultural Consortium (1968-71). Has also served as professor at various Indonesian universities. Was a member of the Bogor kabupaten legislature (1966-68), of the MPRS (1968-69), and of the MPR (1977). Most recently acted as DirectorGeneral of Animal Husbandry in the Department of Agriculture. Is a Protestant.

\title{
Other High-Ranking State Officials in the Cabinet
}

38) Attorney-General

\author{
Lt. Gen. (R) Haji Ismail Saleh SH \\ b. September 7, 1926, in Pati, Central \\ Java
}

Graduated from a HIS in 1941. Apparently completed junior high school (SMP) in Yogya in 1946 while serving in military intelligence (Division III, Yogya) with the rank of sergeant-major. In 1948-49 fought in the Pati-Wonosobo area in Djatikusumo's Ronggolawe Division, with the rank of second lieutenant. Completed high school in 1950, joined the Army's Legal Directorate, and was sent to study at the Military Law Academy from 1952-56. On graduation, was assigned as legal advisor to Regiment 16 (Kediri) in 1957-58, and the Surabaya Municipality Command (19581959). Subsequently served as Military Prosecutor in Surabaya, and in Menado (1959-62). In 1962, returned to the Legal Directorate and was assigned to study at the Military Law College, as well as taking the Army's General Administrative Course (1962-63). From 1965-67 taught at Seskoad, and collaborated with Prof. Dr. Nugroho Notosusanto (currently Minister of Education and Culture) in writing the first of the military's various published accounts of the September 30th Movement [The Coup Attempt of the 'September 30th Movement' in Indonesia, 1968]. In 1967, now a lieutenant-colonel, moved to the Cabinet Secretariat as acting head of the Bureau of Analysis (1967), then head of the Bureau of Analysis and Legislation (1968). In April 1972, rose as colonel to be Deputy Cabinet Secretary, and Assistant to the State Secretary (Sudharmono) in charge of Administrative Affairs. In 1978 became Cabinet Secretary and in 1979, in addition, acting head of the Board for the Coordination of Capital Investment. In mid-February 1981, succeeded Ali Said as Attorney-General, and in April handed over his earlier functions to Ir. Sudartojo.

39) Governor of the Bank of Indonesia

\author{
Dr. Arifin M. Siregar \\ b. February 11, 1934, in Medan, North \\ Sumatra
}

A graduate of Rotterdam's School of Economics (BA) and West Germany's University of Münster (MA and $\mathrm{PhD}$ ), with a specialty in monetary economics and econometrics. After graduating from Münster worked in the Economic Affairs Office of the UN's Bureau of General Economic Research in New York (1961-63); was cofounder and researcher for the UN's Economic and Social Office in Beirut (1963-65). Served as staff economist to the Asian Department of the International Monetary Fund in Washington, DC from 1965-69, and as the IMF resident representative in Laos (and financial advisor to the Laotian government) from 1969-71. During the 1970s became a Director of the Bank of Indonesia. 
40) Commander-in-Chief of the Armed Forces

\author{
Gen. Leonardus Benjamin ("Benny") \\ Moerdani \\ b. October 2, 1932, in Cepu, Central \\ Java \\ (son of R. G. Moerdani Sosrodirdjo, a \\ railway mechanic, and a German- \\ Javanese Catholic woman, with the \\ maiden name of Roech)
}

Is reputed to have joined the Student Army in 1946, when only 13 and barely out of elementary school. Completed SMP in Solo, and began SMA during the Revolution, but when it ended switched to the Army Officers' Training Center (P3AD) in Bandung, where was among the youngest of the c. 500 trainees. On graduation in 1952 , along with classmates Gunawan Wibisono, Soeweno, Dading Kalbuadi, and C. I. Santosa, was accepted into the Infantry Cadre School (SPI--Sekolah Pelatih Infanteri) in Bandung. In 1954-56 served as instructor at the Commando School at Batujajar, outside Bandung, and rose to be chief instructor. Between 1956 and 1958, finished SMA in Bandung (1957) and participated in operations against the Darul Islam, the PRRI, and Permesta, commanding an RPKAD (Paratroop Regiment) unit in the assault on North Sulawesi in 1958. In 1959, attended Jump School, and the Company Officer Course at Bandung, followed by the Amphibious Training Course offered by the US Atlantic Fleet's Naval Amphibious Base at Little Creek, Norfolk, Va. (1960-61). Here is said to have achieved a fluency in English to match his long command of Dutch. Served on his return in Soeharto's Mandala Command, and earned some fame for leading a parachute attack in the Merauke area in June 1962. (Now a major, commanded the Battalion 530/Para, a key Kostrad unit.) In 1963-64 was made the first commander of the RPKAD's Battalion I, then operations officer at regimental headquarters. Early in January 1965 joined the General Staff-2 of Kostrad, and shortly thereafter began a long career in intelligence by becoming Intelligence Assistant for Kostrad's Second Battle Command. In the "precoup" period in the guise of a ticketing official for Garuda Airlines, carried out liaison work in Bangkok with Malaysian officials. After October 1, 1965, worked closely with Ali Murtopo to end Confrontation with Malaysia. From 1967-71 was special liaison officer in Kuala Lumpur, then went to Seoul as chargé d'affaires. Ten days after the "Malari Affair" of January 1974, was summoned home to head Kopkamtib's Intelligence Task Force, and six months later replaced Kharis Suhud as head of the Defense Ministry's Intelligence apparatus. To these offices added those of commander of the Strategic Intelligence Center (August 1977) and deputy head of Bakin, the State Intelligence Agency (May 1978). Has also in recent years served as head of the Team for Handling Vietnamese Refugees and of the Team for the Development of East Timor. Only full general to have the insignia of rank pinned to his chest by President Soeharto himself. Is a Catholic

41) (Acting) Head of the Supreme Audits Board
General Andi Mohammad Jusuf

b. June 23, 1928, in Kajuara, Bone, South Sulawesi

(son of the ruler of Kajuara)

Had a MULO education in the colonial period, followed later by SMA, and stints at the SSKAD (Staff and Command School, Bandung) in 1952-53 and Fort Benning, Ga. (Airborne Advanced Infantry Course). Also completed the Military Attaches' Course in Jakarta. During the Revolution fought on the Republican side in South Sulawesi. In the 1950s rose successively to be Chief of Staff, Regiment 24 in Menado (1953), Operations Officer, T \& T VII in Makasar (1954); commander of the Hasanuddin 
Regiment in Makasar (1957); Chief of Staff Komando Daerah Militer Sulselra, under Andi Mattalatta, in 1959; and commander of Kodam XIV from November 1959 to December 1965, during which time (1961-62) Soeharto's Mandala Command was headquartered in Makasar. Playing an important role in the silent coup of March 11, 1966, was made Minister for Basic and Light Industry (1965-67); Minister of Trade (1967-68); and Minister of Industry (1968-78). In April 1978, appointed Minister of Defense and Security/Commander-in-Chief of the Armed Forces. 


\section{MEMBERS OF THE FOURTH DEVELOPMENT CABINET RANKED ACCORDING TO AGE}

\begin{tabular}{|c|c|c|c|}
\hline Name & Year of Birth & $\begin{array}{l}\text { Age in Years } \\
\text { and Months }\end{array}$ & Ethnic Origin \\
\hline Soeharto & 1921 & 61.9 & Javanese (Yogya) \\
\hline Sudjarwo $(22) *$ & 1922 & 60.11 & Javanese (Solo) \\
\hline Soewardjono (31) & 1923 & 59.10 & Javanese \\
\hline Surono (3) & 1923 & 59.6 & Javanese \\
\hline Tahir (27) & 1924 & 58.9 & Javanese \\
\hline$\overline{\mathrm{L} . \mathrm{S} u}$ tanto (12) & 1924 & 58.7 & Javanese (Yogya) \\
\hline Martono (29) & 1925 & 57.10 & Javanese (Solo) \\
\hline Hutasoit (37) & 1925 & 57.6 & Toba Batak \\
\hline Bustanil Arifin (20) & 1925 & 57.5 & Minangkabau \\
\hline Munawir Sjadzali (32) & 1925 & 57.4 & Javanese (Klaten) \\
\hline Alamsjah (5) & 1925 & 57.3 & Lampunger \\
\hline Suyono (25) & 1926 & 57.0 & Javanese \\
\hline Poniman (15) & 1926 & 56.8 & Javanese (Solo) \\
\hline Supardjo Rustam (13) & 1926 & 56.7 & Javanese \\
\hline Ismail Saleh (38) & 1926 & 56.6 & Javanese \\
\hline Sudomo (28) & 1926 & 56.6 & Javanese \\
\hline Sudharmono (1) & 1927 & 56.0 & Javanese \\
\hline Ali Said (16) & 1927 & 55.9 & Javanese \\
\hline Affandi (21) & 1927 & 55.5 & Sundanese \\
\hline Nani Sudarsono (33) & 1928 & 55.0 & Javanese \\
\hline$\overline{\text { Ali Wardhana (4) }}$ & 1928 & 54.10 & Bantenese \\
\hline Jusuf (41) & 1928 & 54.9 & Buginese \\
\hline Radius Prawiro (18) & 1928 & 54.9 & Javanese (Yogya) \\
\hline Subroto (24) & 1928 & 54.6 & Javanese (Solo) \\
\hline Mochtar Kusumaatmadja (14) & 1929 & 54.1 & Sundanese \\
\hline Rachmat Saleh (19) & 1930 & 52.10 & Javanese \\
\hline Rusmin Nurjadin (26) & 1930 & 52.10 & Javanese \\
\hline Emil Salim (8) & 1930 & 52.9 & Minangkabau \\
\hline Saleh Afiff (11) & 1930 & 52.5 & Cirebonese \\
\hline Nugroho Notosusanto ( 30 ) & 1931 & 51.9 & Javanese \\
\hline Hasrul Harahap (36) & 1931 & 51.4 & Mandailing Batak \\
\hline Sumarlin (6) & 1931 & 51.3 & Javanese \\
\hline Hartarto S. (23) & 1932 & 50.10 & Javanese (Klaten) \\
\hline 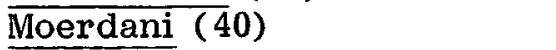 & 1932 & 50.5 & Javanese \\
\hline Wardoyo (35) & 1933 & 49.7 & Javanese \\
\hline Siregar, A. (39) & 1934 & 49.1 & Sipirok Batak \\
\hline Moerdiono (2) & 1934 & 48.7 & Javanese \\
\hline Habibie (7) & 1936 & 46.9 & Buginese \\
\hline Gafur (10) & 1938 & 44.9 & Aceh/Ternate \\
\hline Batubara (9) & 1938 & 44.6 & Toba Batak \\
\hline Harmoko (17) & 1939 & 44.1 & Javanese \\
\hline Kartasasmita, G. (34) & 1941 & $\underline{41.11}$ & Sundanese \\
\hline Average & & 53 yea & \\
\hline
\end{tabular}

* The number in parentheses indicates that of the incumbent's position in the preceding listing.

** The average age of the Fourth Development Cabinet is about three years older that that of the Third Development Cabinet announced in 1978 (c. 50 years). 